\title{
Libertarianie: szczebioczący sekciarze ${ }^{1}$
}

\section{Potomkowie J.S. Milla}

Jakakolwiek dyskusja o stosunkach między konserwatystami (którzy obecnie, jeśli sądzić po sondażach opinii publicznej, stanowią większość wśród obywateli amerykańskich) a libertarianami (którzy, jak pokazały ostatnie wybory, pozostają maleńką, choć niezakazaną, mniejszością) zazwyczaj zaczyna się od pytania o to, co łączy te różne grupy. Te dwie opiniotwórcze grupy łączy wstręt wobec kolektywizmu. Sprzeciwiają się totalistycznemu państwu i ciężkiej ręce biurokracji. Tyle jest oczywiste.

Czy jest jeszcze coś innego, w czym zgodni są konserwatyści i libertarianie? Odpowiedź na to pytanie jest prosta: nie. I niczego takiego nigdy nie będzie. Hasło stworzenia ligi czy koalicji między nimi można porównać do forsowania związku lodu z ogniem.

Rujnującą słabością ideologów zwących siebie libertarianami jest ich fanatyczne przywiązanie do prostej samotnej zasady, tj. do pojęcia osobistej wolności jako jedynego celu porządku społecznego a faktycznie także ludzkiej egzystencji. Libertarianie są staromodni, w tym sensie, że żyją pewnymi abstrakcjami dziewiętnastego stulecia. Do absurdu doprowadzają idee Johna Stuarta Milla (tj. zanim jego żona nawróciła go na socjalizm). By zrozumieć mentalność libertarian 1981 r., warto przypomnieć sobie niewielką książkę opublikowaną ponad 120 lat temu: „O wolności” Johna Stuarta Milla. Argumenty, które w 1859 r. były wątłe (i zostały solidnie odrzucone przez Jamesa Fitzjamesa Stephena) stały się groteskowe w 1981 r. Pozwolę sobie na dygresję na temat znanego eseju Milla. Niektóre książki kształtują charakter epoki, inne go odzwierciedlają. „O wolności” Milla jest tym drugim przypadkiem.

Traktat ten jest produktem pokoju i optymizmu wiktoriańskiej Anglii. Napisany w szczycie tego, co Bagehot określił jako „epoka dyskusji”, jest głosem zanikłej przeszłości XIX-wiecznego melioryzmu. Przyszłość, jak się okazało, nie należała do uczniów Milla.

\footnotetext{
${ }^{1}$ Ang. Libertarians: the Chirping Sectaries. Słowo chirping odwołuje się do II części poematu „Ash-Wednesday” („Środa Popielcowa”) T.S. Eliota: „I rzekł Bóg: / Ożyją te kości? Ożyją / Te kości? A to, co było zawarte / W kościach (już zeschłych) odrzekło, szczebiocząc". Fragment ten to z kolei aluzja do spopielałych kości z wizji Ezechiela (Ez 37, 1-3): „Stała się nade mną ręka Pańska, i wyprowadziła mię w duchu Pańskim, i postawił mię wpośród pola, które było pełne kości. I obwiódł mię po nich wokoło, a było ich bardzo wiele na polu i bardzo suche. I rzekł do mnie: Synu człowieczy, mniemasz, że żyć będą te kości? I rzekłem: Panie, Boże, ty wiesz." Za ustalenie źródła i kontekstu tego słowa dziękuję prof. Jackowi Bartyzelowi [wszystkie przypisy w tym tekście pochodzą od tłumacza].
} 


\section{$6 / 2017$}

Jak Mill był ostatnim z linii brytyjskich empirystów, tak jego esej „O wolności” z uwagami przeczuwającymi nadchodzący despotyzm mas, był bardziej epilogiem liberalizmu klasy średniej niż krzyczącym płaczem.

James Mill, surowy i nadgorliwy ojciec (w jakich to beznadziejnych ludzi zmieniają się ci gorliwcy!) podporządkował swego syna rygorystycznemu programowi prywatnych lekcji. W wieku ośmiu lat J.S. Mill wiedział niemal tyle, ile dziś winien wiedzieć doktor filozofii. Jednak jego rozum pozostał wolny od wyższej wyobraźni i z tego to powodu Mill grzebał na próżno całe swe życie. J.S. Mill stał się głową bez serca, w czym naśladował Jeremy'ego Benthama, choć naprawdę to sam Mill, a nie Bentham, był tym, który stał się przeczyszczonym umysłem.

Jeśli chodzi o emocje i to dość zwyczajne, Mill okazał się niedoskonały - zakochał się w mężatce. F. A. Hayek omówił ten związek i jego konsekwencje dla Milla i jego zwolenników. Mill ostatecznie poślubił tę sawantkę, Harriet Taylor, prekursorkę wojującego feminizmu. On był jej oddany, a ona była oddana humanitarnym abstrakcjom. To pod jej nadzorem napisał „O wolności”. Intelektualni przodkowie dzisiejszego libertarianizmu nie byli skorą do żartów załogą.

„Zarżnąwszy wszystkie swoje zwierzęce nastroje”, jak pisze Ruth Borchard o Millu, „odciął się całkowicie od swych instynktów - chęci życia, instynktownego rozumienia natury, natury ludzkiej w ogóle i swojej w szczególności”. Interesujące byłoby zbadać, jak owe niedoskonałości Milla ukształtowały i wypaczyły cały liberalny ruch w myśli angielskiej i amerykańskiej, a także jak wpłynęły na śladową formę dziewiętnastowiecznego liberalizmu, który dziś nazywa się „libertarianizmem”. Ale na razie musimy to zostawić, zaznaczając jedynie, że to ułomne rozumienie natury ludzkiej z łatwością można zauważyć na kartach eseju Milla „O wolności”.

Książka ta stanowi popis siły logiki i niejakiej elokwencji, ale tkwi w niej błąd Milla, który wierzył, że spokojne społeczeństwo angielskie jego czasów ma być uniwersalnym wzorem dla całej ludzkości. Jest także poraniona za sprawą osobliwego założenia Milla, że większość ludzi, jeśli tylko byliby odpowiednio kształceni, myślałaby i działała dokładnie tak jak John Stuart Mill.

Tymczasem młodszy Mill, w swych esejach o Coleridge’u i Benthamie, słusznie zauważył, że kardynalnym błędem Benthama było założenia, że sprawy ludzkie można zredukować do kilku prostych formuł, stosowanych powszechnie i nieugięcie - podczas gdy wielkie tajemnicze ustanowienie rodzaju ludzkiego jest nieskończenie subtelne i skompli- 
kowane, a nie zdominowane przez zgrabne i drobne abstrakcje. A jednak do tego samego dołu wpada Mill w swym tekście o wolności. W rozdziale wprowadzającym za cel swej pracy uznaje obronę „bardzo prostej zasady, która dotyczy odnoszenia się społeczeństwa do jednostki za pomocą przymusu i nadzoru, za pomocą czy to fizycznej siły w formie kar sądowych, czy moralnego przymusu opinii publicznej. Zasada ta głosi, że jedynym powodem, dla którego ludzkość czy to indywidualnie, czy zbiorowo ma prawo ingerować w wolność działania swych członków, jest samoobrona, a jedyną przyczyną, dla której można prawomocnie stosować przemoc wobec członka cywilizowanej wspólnoty nawet wbrew jego woli, jest zapobieganie szkodzeniu innym"2.

Wydaje się to być atrakcyjną i prostą pojedynczą zasadą. Moim zdaniem wystarczająco określa ona przekonania dwudziestowiecznych libertarian. Problem jednak w tym, że pojedyncze proste zasady, jakkolwiek solidne, naprawdę nie opisują ludzkiego zachowania i na pewno nie są w stanie nim kierować.

James Fitzjames Stephen, szczery człowiek interesu i uczony w prawie, z irytacją spostrzegł ten błąd, który czyni „O wolności” Milla wątłą trzciną w trudnych czasach. W „Wolności, równości, braterstwie”, którą opublikował w 1873 r. Stephen traktuje Milla biczem z kolcami ${ }^{3}$. W jego opinii John Stuart Mill był beznadziejnie naiwny:

„Według mnie pytanie czy wolność jest rzeczą dobrą czy złą, pisał Stephen, „wydaje się tak irracjonalne jak pytanie czy ogień jest dobry czy zły? Jest zarówno dobry i zły zależnie o czasu, miejsca i okoliczności, a pełna odpowiedź na pytanie, w jakich okolicznościach wolność jest dobra a w jakich zła, angażowałoby nie tylko historię powszechną ludzkości, lecz całościowe rozwiązanie problemów, które taka historia ze sobą niesie. Nie sądzę, by stan naszej wiedzy pozwalał nam ogłosić ,bardzo prostą zasadę, która dotyczy odnoszenia się społeczeństwa do jednostki za pomocą przymusu i nadzoru’. Musimy postępować w znacznie ostrożniejszy sposób ograniczając się do takich spostrzeżeń, jakie doświadczenie sugeruje na temat zalet i wad przymusu i wolności w konkretnych przypadkach".

Jak twierdzi Stephen, w każdym zasadniczym założeniu jego argumentu Mill zdradza się z niewłaściwym rozumieniem ludzkiej natury i historii. Wszystkie wielkie osiągnięcia ludzkości, pisze Stephen, osiągnięte zostały dzięki sile, a nie wolnej dyskusji. Jeśli wykluczymy z naszych kalkulacji siłę, szybko damy się podporządkować nietolerancyjnym zachciankom ludzi, którzy nie mają skrupułów, by użyć przeciwko nam przemocy. (W ten

\footnotetext{
2 J. S. Mill, O wolności, przeł. J. Starkel, [w:] tegoż, Pisma o wolności i szczęściu, Warszawa 2016, s. 20-21.

${ }^{3}$ W oryg. a whip of scorpions. Aluzja do 1 Krl 12, 11: „Mój ojciec karcił was biczami, ja zaś będę was karcił biczami z kolców".
} 


\section{$6 / 2017$}

sposób, ktoś może zauważyć, dwudziestowieczni libertarianie uczyniliby nas bezbronnymi wobec sowieckiej Rosji.) Trzeba być skończonym szaleńcem, żeby tolerować każdy rodzaj opinii, w każdej sprawie, tylko w imię kultu abstrakcyjnej „,wolności”. Opinia bowiem łatwo znajduje swój wyraz w działaniu, a fanatycy, których tolerowaliśmy nie będą nas tolerować, gdy znajdą się u władzy.

Gwałtowny bieg wydarzeń w naszym stuleciu dostarczył dowodu dla argumentu Stephena. Czy świat stał się lepszy dzięki swobodnej dyskusji nazistowskiej tezy, że Żydzi winni być traktowani gorzej niż ludzie? Właśnie ten temat został przedstawiony do dyskusji ludności jednego z najbardziej zaawansowanych i wykształconych narodów współczesnego świata. Wtedy to awanturnicza załoga, która najlepiej poradziła sobie w tym sporze, przeszła do działania ze znaną nam dziś przerażającą elegancją. Zrozumieliśmy ogromnym kosztem, co Burke miał na myśli mówiąc o „rozpasanej tolerancji”. Nieustająca gorliwość represji nie jest także odpowiedzią na złożone trudności wolności i porządku. To, o czym mówił Stephen i co my dzisiaj uznajemy, to to, że wolności nie można utrzymać czy rozszerzyć za pomocą apeli o swobodną dyskusję, słodkiej rozsądności czy prostej samotnej zasady.

Od czasów Milla libertarianie niczego nie zapomnieli i niczego się nie nauczyli. Milla i współczesnych libertarian podobnie przeraża posłuszeństwo nakazom zwyczaju. W rzeczywistości prawdziwym zagrożeniem jest to, że zwyczaj, nakaz i tradycja mogą zostać całkowicie obalone - czyż nie to właśnie zdarzyło się w większości świata? - przez neoteryzm, czyli żądzę nowości i że ludzie nie będą lepsi od letnich much, nieświadomi mądrości swych przodków, kształtujący każdą opinię jedynie pod presją chwilowej mody, słabostek, namiętności chwili.

Ktoś może zaprotestować twierdząc, że libertariańskie pojęcia sięgają czasów przed Millem. To prawda. Co więcej, na długo przed Stephenem zostały odrzucone m.in. przez Johna Adamsa w listach z Thomasem Jeffersonem czy Johnem Taylorem z Caroline. Pierwszym wigiem był diabeł, jak zawiadamia nas Samuel Johnson. Może lepiej byłoby powiedzieć, że diabeł był pierwszym libertarianinem. „Słuchajcie, jestem pełen pychy!” Wieczny libertarianin, jak szatan, nie może znieść żadnej władzy doczesnej czy duchowej. Próbuje być inny, tak w kwestii moralności jak polityki. W bardzo tolerancyjnym społeczeństwie jakim jest dzisiejsza Ameryka taki bunt przeciwko władzy dla samej zasady może prowadzić z braku czegoś bardziej zaskakującego do zrobienia do perwersji dla samej zasady. Między libertarianizmem a libertynizmem nie ma pewnej granicy. 
Dlatego typowy libertarianin naszych czasów rozkoszuje się ekscentryzmem włączając w to, często, ekscentryzm seksualny (co zauważył ostry w swych poglądach psycholog dr Ernest van den Haag). Czyż sam John Stuart Mill nie pochwalał ekscentryzmu jako formy obrony przed otępiającym konformizmem demokratycznym? Nasz reprezentatywny libertarianin bawi się przednio zarówno, gdy popisuje się ekscentryzmem w polityce jak i moralności. Jednak, jak twierdzi Stephen w komentarzu do Milla, „Ekscentryczność jest znacznie częściej oznaką słabości niż siły. Z reguły słabość pragnie zwracać na siebie uwagę błahymi różnicami, podczas gdy siła woli tego uniknąć”.

W pełni się z tym zgadzam. Przechodząc od dziewiętnastego do dwudziestego wieku, w 1929 r. natrafiamy na pisarza bardzo niepodobnego do Milla, który wykazał absurdy nienaturalnej ekscentryczności i doktrynerskiego libertarianizmu: G. K. Chesterton. Gabriel Gale, intuicyjny bohater zbioru opowiadań Chestertona pod tytułem „Poeta i lunatycy”, upomina się o centryczność: „Geniusz nie musi być ekscentryczny! Powinien być rdzeniem kosmosu, a nie znajdować się na obracających się krawędziach. Ludziom wydaje się być komplementem, gdy oskarża się kogoś o bycie autsajderem lub mówi się o ekscentryczności jakiegoś geniusza. Co by pomyśleli, gdybym powiedział, że chciałbym prosić Boga jedynie o to, bym miał centryczności geniuszu?"

Nikt nigdy nie oskarżał libertarian o bycie dotkniętym centrycznościami geniuszu: bowiem marzenie o absolutnej własności prywatnej jest jedną z tych wizji, które pochodzą spomiędzy bram z kości słoniowej. A przeraźliwe tempo zmian jakie zachodzą w społeczeństwie ruchem odśrodkowym wyrzuca libertarian na zewnątrz, nawet do najdalszej ciemności, gdzie płacz i zgrzytanie zębów. Ostateczne wyzwolenie od religii, konwencji, zwyczaju i porządku jest zagładą - „Wyrzuceni za tory zmarzłej Niedźwiedzicy / Miazgą atomów"4.

W „Poecie i lunatykach” Chesterton opowiada nam przypowieść o tak rozpasanej wolności, historię pt. „Żółty ptak”. Do angielskiego domu na wsi przyjeżdża profesor Iwanow, rosyjski badacz, który opublikował „Psychologię wolności”. Jest zagorzałym zwolennikiem emancypacji, ekspansji i eliminacji ograniczeń. Zaczyna od wyzwolenia kanarka z klatki, co kończy się jego rozerwaniem na strzępy w pobliskim lesie. Następnie wyzwala złotą rybkę rozbijając jej akwarium. Na koniec wysadza siebie i piękny stary dom, w którym był gościem.

\footnotetext{
${ }^{4}$ Cytowany fragment pochodzi z poematu T.S. Eliota pt. „Gerontion”. Podaję w przekładzie Cz. Miłosza.
} 


\section{$6 / 2017$}

„Czym w istocie jest wolność?” dopytuje obserwator tej serii wydarzeń - Gabriel Gale, alter ego samego Chestertona. „Po pierwsze i przede wszystkim jest to na pewno zdolność rzeczy do bycia sobą. W pewien sposób żółty ptaszek był wolny w swej klatce. Był wolny w tym, że był sam. Był wolny, bo mógł śpiewać. W lesie czekałby go marny los i wkrótce zamilkłby na wieki. Potem pomyślałem, że bycie sobą, czyli wolnym, jest samo $\mathrm{w}$ sobie ograniczeniem. Jesteśmy ograniczeni naszymi mózgami i ciałami. Jeśli się z tego wyzwolimy, przestaniemy być sobą, a może nawet przestaniemy być czymkolwiek”.

Rosyjski psycholog nie był w stanie znieść koniecznych warunków ludzkiego istnienia. Musiał wyeliminować wszelkie ograniczenia. Nie mógł znieść „okrągłego więzienia” zwieńczonego niebem. Ale jego alternatywą było zniszczenie: jego samego i jego otoczenia. I wybrał tę alternatywę. Stał się niczym więcej jak miazgą atomów. Oto ostateczna wolność gorliwego libertarianina. Gdyby, per impossibile, społeczeństwo amerykańskie miało zaakceptować rządy libertariańskich ideologów - republika ta skończyłaby jako miazga atomów i to w rosyjskim stylu.

\section{Dlaczego nie można im pobłażać?}

Mimo wszystko trzeba obiektywnie rzecz biorąc powiedzieć coś na korzyść rozczłonkowanego profesora Iwanowa. W odniesieniu do mojej ostatniej wypowiedzi dla Heritage Foundation, pan Marion Montgomery, pisarz i krytyk z Georgii, pisze do mnie co następuje: „Libertarianie mnie przerażają. Od libertariańskiego anarchisty wolę już rosyjskiego anarchistę, który przynajmniej ma poczucie głębokiego zaniepokojenia i wrażliwość (z czego Dostojewski zrobił świetny użytek). Wśród libertarian jest jakiś dekadencki zapał, który czyni z nich krzyż nie do zniesienia dla konserwatyzmu”.

Tak więc współczesny typowy libertarianin nie ma poczucia humoru, jest nietolerancyjny, przemądrzały, źle wykształcony i tępy. Rosyjski anarchista starej daty był przynajmniej wyraźny, pełen życia i wiedział do jakiej płci przynależy.

Ale czy nie przedstawiam libertarian w złym świetle? Czy nie znam samozwańczych libertarian, którzy są miłymi, starszymi, bogobojnymi, patriotycznymi, cnotliwymi i zadowolonymi z życia dżentelmenami? Oczywiście znam takich. Są to ludzie, którzy przez nieporozumienie lokują pieniądze w fantazmatach. Tacy dżentelmeni nazywają siebie „libertarianami” tylko dlatego, że wierzą w osobistą wolność i nie rozumieją dla jakich ekstrawagancji użyczają swych nazwisk wspierając doktrynerską sprawę libertarian i ich publikacje. Jeśli jakaś osoba określa siebie jako „libertarianin”, ponieważ wierzy w trwały porządek moralny, konstytucję Stanów Zjednoczonych, wolną przedsiębiorczość, stare 
amerykańskie style życia, w istocie jest konserwatystą, który nie rozumie podstawowych pojęć politycznych.

Nie potępiam zatem ludzi o dobrych intencjach, lecz tylko ich błędne samookreślenie swego stanowiska. Raczej ujawniam aspiracje doktrynerów, którzy zamknęli się w „libertariańskiej” ideologii, równie ograniczonej i nierzeczywistej co marksizm, choć mniej przekonującej niż to upadłe złudzenie.

Dlaczego ci doktrynerscy libertarianie, z nielicznymi wyjątkami, są tak bardzo dziwnymi ludźmi, którzy irytują nawet tak serdecznych ludzi jak Marion Montgomery? Dlaczego prawdziwi konserwatyści z niechęcią podchodzą do jakichkolwiek kontaktów z nimi? (Nota bene, co jakiś czas można przeczytać o dwóch obozach rzekomych konserwatystów: „tradycjonalistyczni konserwatyści i libertariańscy konserwatyści”. To tak jakby dziennikarze sklasyfikowali chrześcijan jako „protestanckich chrześcijan” i „islamskich chrześcijan”. Libertariański konserwatysta to równie częsty przypadek co żydowski nazista.)

Dlaczego sojusz konserwatystów z libertarianami jest czymś niewyobrażalnym? Dlaczego właściwie takie porozumienie zaprzepaściłoby wszystko, co osiągnęli konserwatyści w Stanach Zjednoczonych?

Otóż prawdziwi libertarianie są szaleni - metafizycznie szaleni. Obłęd odpycha, a polityczny obłęd w szczególności. Nie chcę przez to powiedzieć, że są niebezpieczni. Są po prostu odpychający jak niektórzy nieszczęśliwi pensjonariusze zakładów psychiatrycznych. Nie zagrażają naszemu krajowi i naszej cywilizacji, ponieważ jest ich niewielu i wydaje się, że będzie ich coraz mniej. (Mam tu oczywiście na myśli naszych rodzimych amerykańskich libertarian, a nie te polityczne sekty, jak Czerwony Brygady we Włoszech, które wyniosły libertariańskie pojęcia do większych i zuchwalszych rozmiarów.) Nie ma zagrożenia, że amerykańska polityka, zagraniczna czy wewnętrzna, znajdzie się pod choćby najmniejszym wpływem libertariańskich argumentów. Stare dobre sprawy bimetalizmu, pojedynczego podatku czy prohibicji mają większą szanse powodzenia w ostatnich dekadach tego stulecia niż program libertarianizmu. Nikt nie wybiera na partnera nawet nieszkodliwego politycznego lunatyka.

Uważam, że libertarianie tworzą to, co T.S. Eliot nazwał „świergoczącą sektą", ideologiczną kliką dzielącą się na coraz to mniejsze i dziwniejsze sekty, rzadko się ze sobą zgadzającą. Edmund Burke nazwał obrazowo takich małych politycznych sekciarzy „insektami chwili”, równie głośnymi, co nieudolnymi wobec konserwatywnej siły pasącego się 
bydła na angielskim pastwisku. Jeśli ktoś ma za przyjaciół szczebioczących sekciarzy, nie potrzebuje już wrogów.

Co mam na myśli mówiąc, że dzisiejsi libertarianie w Ameryce są metafizycznie szaleni i tak odrzucający? Dlaczego dogmaty libertarianizmu były tyle razy odrzucane, zarówno dialektycznie jak i przez doświadczenie, że byłoby nudne ponownie przechodzić przez całą historię głupoty. Z braku miejsca, przedstawię poniżej tylko kilka z najbardziej widocznych braków libertarianizmu jako wiarygodnego moralnego i politycznego sposobu myślenia. Są to te różnice od konserwatywnego stanowiska na temat kondycji ludzkiej, które uniemożliwiają jakąkolwiek koalicję między konserwatystami i libertarianami.

1. Wielka linia podziału we współczesnej polityce - jak przypomina nam Eric Voegelin - przebiega nie między totalitarystami z jednej strony a liberałami (czy libertarianami) z drugiej. Leży ona raczej między tymi, którzy wierzą w jakiegoś rodzaju transcendentny porządek moralny oraz tymi, którzy biorą tą naszą efemeryczną egzystencję za wszystko, co najważniejsze - oddane głównie produkcji i konsumpcji. W tym rozróżnieniu między owcami i kozłami, libertarianie muszą być sklasyfikowani jako kozły, tj. jako utylitaryści nie uznający jakichkolwiek transcendentnych sankcji za postępowanie. W efekcie, są konwertytami na Marksowski materializm dialektyczny. Konserwatyści odżegnują się od nich ze względów pryncypialnych.

2. W każdym społeczeństwie porządek jest podstawową potrzebą wszystkich. Wolność i sprawiedliwość mogą być ustanowione tylko wtedy, gdy porządek jest w miarę zapewniony. Ale libertarianie dają pierwszeństwo abstrakcyjnej wolności. Konserwatyści, wiedząc, że „wolność tkwi w jakiejś odczuwalnej rzeczy" są świadomi tego, że prawdziwą wolność można znaleźć jedynie w ramach porządku społecznego takiego jak porządek konstytucyjny Stanów Zjednoczonych. Wychwalając absolutną i nieokreśloną wolność kosztem porządku libertarianie narażają na niebezpieczeństwo te same wolności, które sławią.

3. Co spaja społeczeństwo? Libertarianie odpowiedzą, że spoiwem społeczeństwa (o ile są w stanie zaakceptować jakiekolwiek więzi) jest interes własny, ściśle połączony w ogniwo zapłaty gotówką. Konserwatysta wyznaje, że społeczeństwo jest wspólnotą dusz, łączącą umarłych, żywych i tych jeszcze nienarodzonych i że jego spoiwem jest to, co Arystoteles nazywał przyjaźnią, a chrześcijanie zwą miłością bliźniego. 
4. Libertarianie (jak anarchiści i marksiści) wierzą, że ludzka natura jest dobra, choć skrzywdzona przez pewne instytucje społeczne. Konserwatyści, odwrotnie, utrzymują, że „w Adamie wszyscy zgrzeszyli”: natura ludzka, choć złożona z dobra i zła, jest nieodwracalnie zraniona; jeśli wszyscy ludzie są niedoskonali, to doskonałe społeczeństwo jest niemożliwe. Libertarianin tym samym kontynuuje swą iluzoryczną podróż do Utopii. Konserwatysta wie, że to droga do Averno.

5. Libertarianin uznaje państwo za wielkiego prześladowcę. Konserwatysta zaś twierdzi, że państwo jest nakazane przez Boga. Jak powiedział Burke, „On, który dał nam naszą naturę, by była doskonalona przez cnotę, pragnął również koniecznych środków jej doskonalenia. - Pragnął zatem państwa - Chciał związać go ze źródłem i pierwotnym archetypem wszelkiej doskonałości”. Bez państwa, jak twierdził Augustyn wiele stuleci przed Hobbesem, życie człowieka jest biedne, paskudne, brutalne i krótkie. Libertarianie mieszają państwo z rządem. Lecz rząd - jak pisał dalej Burke - „jest wytworem ludzkiej mądrości powstałym po to, by zaspokoić ludzkie pragnienia”. A jednym z najważniejszych spośród tych ludzkich pragnień jest „dostateczne powstrzymywanie ludzkich namiętności. Społeczeństwo wymaga nie tylko podporządkowania namiętności jednostek, lecz także, aby czy to w masie czy ciele zbiorowym, tak jak w jednostce, skłonności ludzi były wielokrotnie powstrzymywane, ich wola kontrolowana, a ich namiętności opanowane. Można to uczynić tylko mocą spoza nich samych, a nie, używając jej funkcji w podporządkowaniu tej woli i tym namiętnościom, które ma za zadanie okiełznać i stonować". W skrócie, nadrzędnym zadaniem rządu jest powstrzymywanie. Dla libertarian jest to anatema, dla konserwatystów - artykuł wiary.

6. Libertarianin uważa, że świat jest przede wszystkim sceną dla pyszniącego się ego. Konserwatysta postrzega siebie natomiast jako pielgrzyma w domenie tajemnicy i zdziwienia, gdzie obowiązek, dyscyplina i ofiara są pożądane i gdzie nagrodą jest miłość, która przekracza wszelkie zrozumienie. Konserwatysta uznaje libertarianina za bezbożnego w znaczeniu antycznej rzymskiej pietas. Libertarianin nie czci tradycyjnych wierzeń i zwyczajów, świata naturalnego, swego kraju, ani nieśmiertelnej iskry w swych bliźnich. Kosmos libertarianina 
to rzeczywistość jałowa, pozbawiona miłości, „okrągłe więzienie”. „Ja jestem i nikt prócz mnie”, mówi libertarianin. „Zostaliśmy stworzeni, by współpracować, jak ręce, jak nogi”, odpowiada konserwatysta słowami Marka Aureliusza.

Po co pomnażać te fundamentalne różnice? Już te, które wymieniłem wystarczą, by udowodnić absolutną niezgodność obu stanowisk. Jeśli ktoś miałby zadowolić się porównaniem poglądów konserwatystów i libertarian na naturę wolności, dalej nie osiągnęlibyśmy kompromisu. Jak napisał John Adams do Johna Taylora, istnieje wolność wilków, ale też istnieje wolność cywilizowanego człowieka. Konserwatysta nie będzie tolerował drapieżnej wolności. Podobnie jak Dostojewski wie, że ci, którzy zaczynają od absolutnej wolności kończą na absolutnej tyranii. Konserwatysta opowiada się raczej za tym, co Burke nazwał „opatentowanymi uprawnieniami”, powstałymi powoli i boleśnie w ramach porządku państwowego, usankcjonowanymi przepisami.

Ale czy skoro libertarianin i konserwatysta nie mają nic wspólnego, w czym by się zgadzali, to nie mogą się z czymś w równym stopniu nie zgadzać? Czy nie mogą przyjmować wspólnego stanowiska wobec skłonności nowożytnego państwa do omnikompotencji? Z pewnością oba poglądy dostrzegają, że współczesne rządy, nawet $\mathrm{w}$ tak konstytucyjnym porządku jak Stany Zjednoczone, cierpią na libido dominandi. Nadrzędnym zadaniem rządu, powiedzą konserwatyści, jest utrzymywanie pokoju: poprzez powstrzymywanie zewnętrznych wrogów oraz utrzymywanie sprawiedliwości wewnątrz państwa. Jeśli rząd dalece wykracza poza ten cel, popada $\mathrm{w}$ tarapaty nie będąc $\mathrm{w}$ stanie poradzić sobie z zarządzaniem całością życia. W tej kwestii rzeczywiście libertarianin i konserwatysta mogą się zgodzić. Ale libertarianie, lekkomyślnie pędząc do przeciwnej skrajności, pozbawiliby rząd efektywnej władzy zapewniania obrony czy powstrzymywania gwałtowników i krzywdzicieli. Mając na myśli libertarian, konserwatyści powtarzają aforyzm Burke’a: „Ludzie niepowściągliwi nigdy nie będą wolni. Ich namiętności są im za kajdany”.

Zatem w naturze rzeczy konserwatyści i libertarianie nie mogą zawrzeć traktatu przyjaźni. Konserwatyści nie mają intencji poszukiwania kompromisu z socjalistami. Ale nawet taki sojusz, jakkolwiek absurdalny, jest bardziej do pomyślenia niż koalicja konserwatystów i libertarian. Socjaliści przynajmniej deklarują istnienie jakiegoś rodzaju porządku moralnego. Libertarianie są całkowicie pozbawieni gruntu.

Z konieczności zarysowane tu pryncypialne różnice dotyczą spraw praktycznych i aktualnych. Ostatnio Partia Libertariańska w swym programie wyborczym ogłosiła, że przyszłe matki powinny mieć prawo do aborcji na żądanie. Dla myślącego konserwatysty 
rzeź niewiniątek jest największym złem. Jakie to przyjazne praktyczne porozumienie może być osiągnięte między dwoma tak diametralnie przeciwstawnymi poglądami?

Bez wątpienia libertarianie, od dawna przyzwyczajeni do ukrywania się w jaskini Adullam, niedługo zaczną nazywać pana Reagana socjalistą. Przeciwności sprzyjają powstawaniu dziwnych kompanii, ale obecny sukces konserwatystów zniechęca ich do tego, by legnąć niczym baranki przy boku libertariańskich hien. W dużej mierze zwycięstwo pana Reagana i jego przyjaciół przyczynia się do odnowy starego amerykańskiego porządku moralnego związanego z chrześcijańską koncepcją społeczeństwa. Zwycięzcy nie kwapią się do dialektycznego mariażu z ugrupowaniem, które neguje podstawowe przesłanki porząaku społecznego i obywatelskiego w tym kraju.

Jest rzeczą wielkiej wagi w istocie, by amerykańscy konserwatyści odcięli się w całości od małej zgorzkniałej resztki zwanej libertarianami. W chwili wymagającej dalekiego spojrzenia i samozaparcia, sojusz z grupą ufundowaną na doktrynerskim egoizmie byłby absurdem, a w praktyce - działaniem niszczącym. Nie chodzi o to tylko, że współpraca z nieistotną szczebioczącą sektą byłaby politycznie nieopłacalna. Powiem więcej, taki związek mógłby zdyskredytować konserwatystów dając argument kolektywistycznym adwersarzom uporządkowanej wolności. Gdy przeminą niebo i ziemia być może umysł konserwatywny i umysł libertariański będą mogły połączyć się w postaci syntezy - ale nie wcześniej. W międzyczasie, zaryzykuję następującą przepowiednię, bardziej inteligentne i świadome osoby spośród nielicznych libertarian będą ciążyć ku polityce jako sztuce tego, co możliwe, przesuwając się tym samym w stronę obozu konserwatywnego. Na sądzie ostatecznym libertarianizm może okazać się zredukowany do mniejszości jednego, a jego imię nie będzie legion, lecz Rothbard.

(C) Modern Age, Fall 1981

przełożył Łukasz Święcicki 